\title{
The Analysis of Italian Plant Agrobiodiversity Databases Reveals That Hilly and Sub-Mountain Areas Are Hotspots of Herbaceous Landraces
}

\author{
Luca Giupponi $^{1,2}$ (D) Davide Pedrali ${ }^{1}$, Valeria Leoni ${ }^{1, *}$, Alessia Rodari ${ }^{1}$ and Annamaria Giorgi ${ }^{1,2}$ \\ 1 Centre of Applied Studies for the Sustainable Management and Protection of Mountain Areas-CRC \\ Ge.S.Di.Mont., University of Milan, Via Morino 8, 25048 Edolo (BS), Italy; luca.giupponi@unimi.it (L.G.); \\ davide.pedrali@unimi.it (D.P.); alessia.rodari@unimi.it (A.R.); anna.giorgi@unimi.it (A.G.) \\ 2 Department of Agricultural and Environmental Sciences-Production, Landscape and Agroenergy-DiSAA, \\ University of Milan, Via Celoria 2, 20133 Milan (MI), Italy \\ * Correspondence: valeria.leoni@unimi.it
}

check for updates

Citation: Giupponi, L.; Pedrali, D.; Leoni, V.; Rodari, A.; Giorgi, A. The Analysis of Italian Plant Agrobiodiversity Databases Reveals That Hilly and Sub-Mountain Areas Are Hotspots of Herbaceous Landraces. Diversity 2021, 13, 70. http:/ / doi.org/10.3390/d13020070

Academic Editor: Mario A. Pagnotta Received: 19 January 2021

Accepted: 6 February 2021

Published: 9 February 2021

Publisher's Note: MDPI stays neutral with regard to jurisdictional claims in published maps and institutional affiliations.

Copyright: (c) 2021 by the authors. Licensee MDPI, Basel, Switzerland. This article is an open access article distributed under the terms and conditions of the Creative Commons Attribution (CC BY) license (https:/ / creativecommons.org/licenses/by/ $4.0 /)$.

\begin{abstract}
Landraces are an agri-food and historical-cultural heritage but are undergoing losses worldwide. Italy is taking action to counteract this problem by following European guidelines. One of the most important measures is the Agrobiodiversity National Register (ANR), but 12 Italian regions currently appear without any landraces and around $80 \%$ of the landraces listed are trees, with less detailed data on herbaceous species. The aim of this study is to investigate the situation for Italian herbaceous landraces preserved on farms (in situ) by merging and analyzing data contained in the main databases on plant agrobiodiversity in Italy. Data were georeferenced, organized by botanic families and Italian regions, and analyzed by GIS and R. A total of 1615 herbaceous landraces were found (versus the 416 recorded in the ANR). Poaceae, Fabaceae, and Solanaceae together comprise $70 \%$ of all herbaceous landraces and are mostly preserved/grown in areas between 150 and $800 \mathrm{~m}$ a.s.l. Some hilly and sub-mountain areas of the Apennines and the Alps are hotspots of herbaceous landraces due to anthropic and environmental factors. The results of this research will be useful to enrich the ANR and trigger actions of characterization, conservation, and promotion of these plant resources.
\end{abstract}

Keywords: agrobiodiversity; crops; herbaceous plants; in situ conservation; plant diversity; plant genetic resources; traditional cultivars

\section{Introduction}

The safeguarding of agrobiodiversity is an extension of the concept of biodiversity conservation that refers specifically to the varieties/races of plant, animal, and microbe species of agricultural interest, as well as crop wild relatives. The latter have contributed to crop domestication for millennia, providing important genetic resources adapted to the environment and climate changes and can represent a valuable resource for innovative lower-input agricultural systems [1]. In the past, there were many more landraces, understood as dynamic populations of cultivated plants that have a historical origin and distinct identity and lack formal crop improvement, as well as often being genetically diverse, locally adapted, and associated with traditional farming systems [2]. Landraces constitute unique genetic resources for genetic crop improvement programs [3-5] and a source of food diversity available to humans and other living beings [6].

These genetic resources have undergone (and are undergoing) heavy losses over the last decades [7,8]. The Food and Agriculture Organization of the United Nations (FAO) estimates that about $75 \%$ of global agrobiodiversity has been lost over the last century and that three quarters of food worldwide is produced by only 12 plant species and five animal species [7-12]. This loss represents a serious problem that has prompted governments at global and local levels to take immediate action: in recent decades, there have been several 
international conferences during which scientists and politicians were able to discuss issues related to the conservation of agrobiodiversity, including the Convention on Biological Diversity (CBD) [13-17] and the International Treaty on Plant Genetic Resources for Food and Agriculture [18] on which the Global Strategy for Plant Conservation is based [19]. This resulted in the drawing up of international guidelines and strategies such as, for the European Union (EU), the EU Biodiversity Strategy 2020 [20] and the 2030 Agenda for Sustainable Development [21], including principles which were integrated into some European Directives [22-24] and hence acquired by EU member states. The European Register of Conservation Varieties represents one of the most modern instruments adopted by the EU for in situ conservation of landraces [25]. It envisages the figure of the "custodian farmer" who is responsible for the production of seed (produced in purity) in the area where the landraces are traditionally cultivated (excluding limited cases).

Italy is the only country in Europe to have implemented directive 98/95 before Directive $62 / 2008$ by ad hoc national-level regulations [26] and is legislating to counteract the problem of landrace loss by following EU guidelines. With the recent law of 1st December 2015 n. 194 ("Provisions for the conservation and enhancement of biodiversity of agricultural and food interest") [27], Italy recognized the principles for the establishment of a national system of conservation and enhancement of biodiversity of agricultural and food interest, aimed at protecting local genetic resources from the risk of extinction and/or genetic erosion. This phenomenon has been widely demonstrated for Italy [28], with an estimated genetic erosion rate of $72.8 \%$ in the south of the Peninsula [9]. This protection system provides for the creation of an Agrobiodiversity National Register which was set up in December 2019 [29] (Ministerial Decree 2019/39407; https: / / rica.crea.gov.it/APP/anb/) and has collected all information on landraces submitted by the regions to the Italian Ministry for Agriculture and Forestry (MiPAAF) in recent years.

Although this an important step at a national level to preserve Italian agrobiodiversity, various issues have led to information gaps in the records and much of the agrobiodiversity of many regions has yet to be characterized [30] and therefore has not been included in the register. Moreover, information is not coherent with other databases and information sources [30]. The register currently shows that out of 20 Italian regions, 12 have no landraces, while as regards the regions that provided data, around $80 \%$ of the landraces listed are tree species, with less detailed data collection on herbaceous species (Figure 1). Herbaceous plants require particular attention due to the high number of species/varieties and their vulnerability among the various taxa that make up agrobiodiversity. This is probably due to the lack of information regarding garden crops [31,32] as many of the collecting missions carried out in the past were mainly concentrated on major crops grown in fields "easy" to reach. Furthermore, cultural information (historical memory), together with the multiplication/conservation of landraces conducted by local farmers and exchange of seeds, has always had an informal aspect not subject to written rules [33]. Hence, a significant number of unknown landraces could still exist isolated in farms [34]. In this sense, strategies to preserve herbaceous landraces which have virtually disappeared are important [30]. The latest communication of the European Commission [35] (EU COM $380,20.5$.2020) states that by 2030 , it is necessary to invert the trend of genetic erosion in agriculture by, for example, the use of traditional breeds and cultivars.

National programs for genetic resources supported by several gene banks and the International Board on Plant Genetic Resources (IBPGR, presently Bioversity International) conducted more than 500 collection missions, which contributed significantly to the generation of agrobiodiversity reports and inventories along with numerous Directories of Germplasm Collections [36]. Many different organisms are responsible for the collection and conservation ex situ of plant genetic resources for food and agriculture (PGRFA) such as the international center genebanks and the international collections hosted by CGIAR Centers, which are important components of the United Nations Food and Agriculture Organization's global system of conservation and use of PGRFA, as IBPGR is. As regards 
Italy, the first genebank was set up in Bari [1] in the 1970s, followed by many more under the National Research Council (CNR) and Council for Research in Agriculture (CREA).

Although genebank accessions could fulfil the conditions set by the EU directive for conservation varieties, their lists could be completed by a germplasm that is not part of the government genebank system and is actively managed by farmers and gardeners organized in seed savers' associations or other individuals engaged in the development of informal seed supply systems [37].

In Bulgaria, a study was conducted on local horticultural cultivars and populations to summarize the information available for the germplasm of local accessions collected from their typical growing regions, resulting in a collection of 2057 accessions and bases comprising important phenological, morphological, and economic traits, allowing their rational use in breeding and practice [38]. In Germany, a project started in 2007 for the development of a federal state reporting and documentation system for in situ (CWR) and on-farm (landraces) to implement the National Inventory on PGRFA (PGRDEU), containing passport data for more than 150,000 accessions of German ex situ holding institutions [37]. Further, in other continents, alliances of local and national governments, research centers, and farmers' associations that preserve landraces in situ proved fundamental to create an inventory of traditional varieties and prevent the genetic erosion of landraces [39].

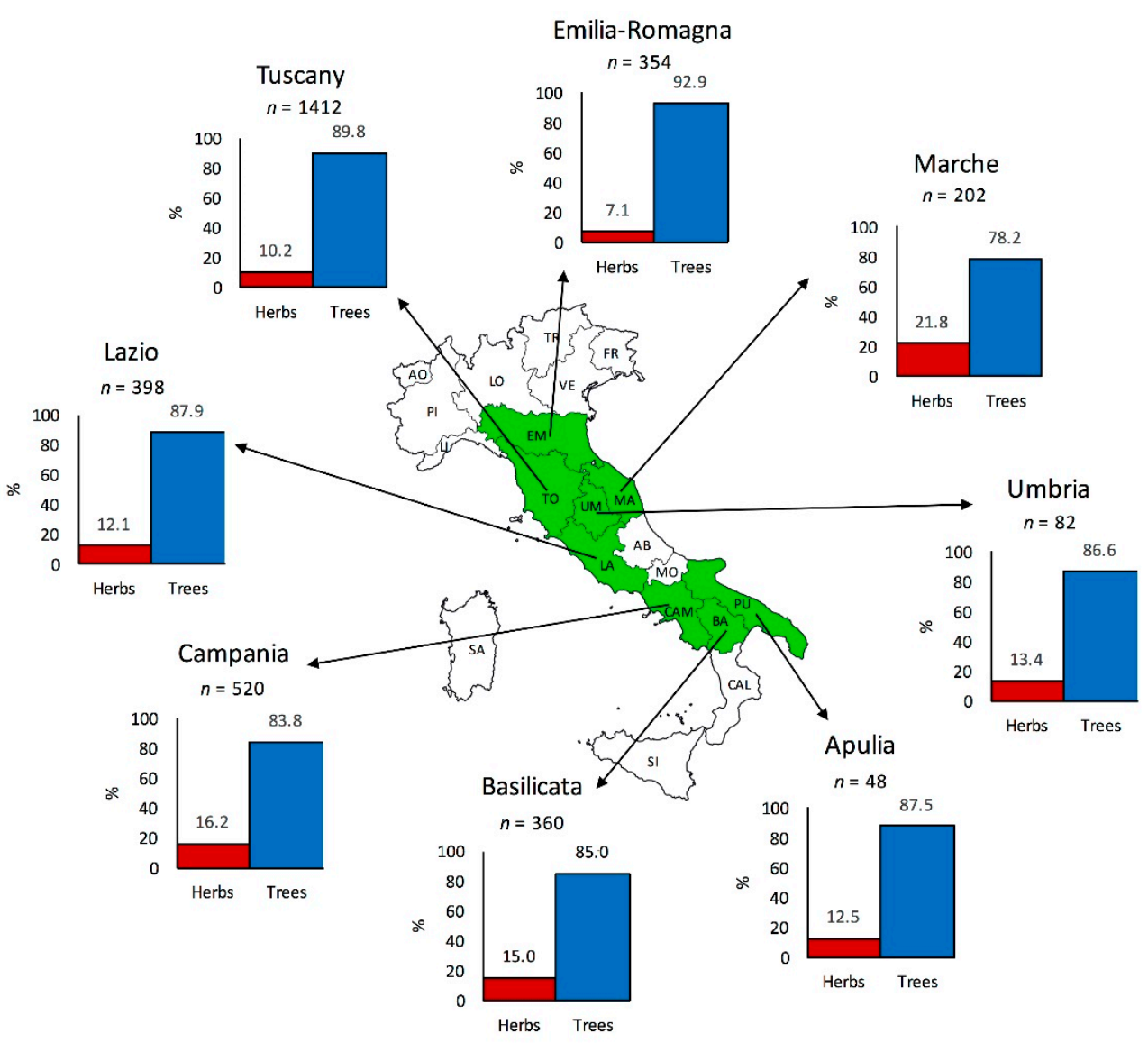

Figure 1. Regions of Italy that provided (in green) and that did not provide (in white) data concerning their landraces to MiPAAF for the construction of the Agrobiodiversity National Register. The number of landraces and the percentage of grasses (red bars) and trees (blue bars) of each region are reported. Key of Regions: AO, Aosta Valley; PI, Piedmont; LO, Lombardy; TR, Trentino-Alto Adige; VE, Veneto; FR, Friuli-Venezia Giulia; LI, Liguria; EM, Emilia-Romagna; TO, Tuscany; UM, Umbria; MA, Marche; AB, Abruzzo; LA, Lazio; MO, Molise; CAM, Campania; PU, Apulia; BA, Basilicata; CAL, Calabria; SI, Sicily SA, Sardinia. 
As regards Italy, even if, as explained above, the Agrobiodiversity National Register currently contains poor data on herbaceous landraces, other open sources of data, such as inventories produced by MiPAAF, universities and research centers, or foundations for the conservation of agrobiodiversity such as Slow Food, can provide a considerable amount of information on Italian herbaceous landraces.

The aim of this study was to collect as much detailed and complete information as possible regarding herbaceous landraces in Italy. This target was pursued by merging and analyzing the data contained in the main databases of cultivars (preserved on-farm, in situ). Specifically, data were analyzed considering the appurtenance of each landrace to plant families and their distribution throughout the Italian territory, focusing on altitudinal and regional distribution, to allow the identification of herbaceous agrobiodiversity hotspots. The families with the highest number of landraces were further investigated by analyzing the altitudinal distribution and allocation in the main genus/species.

This research was supported by the Department for Regional Affairs and Autonomies (DARA) of the Italian Presidency of the Council of Ministers to implement the data of the Agrobiodiversity National Register and launch actions to promote these resources.

\section{Materials and Methods}

The herbaceous landraces inventory was elaborated following the considerations of Maxted et al. in [40]. In detail, for the purposes of creating a complete and updated inventory of herbaceous landraces, the following inventories were considered:

- The Agrobiodiversity National Register provided to the research team by MiPAAF (Italian Ministry of Agriculture and Forestry) thanks to the DARA-CRC Ge.S.Di.Mont. agreement. Dataset: 3376 records.

- The first Italian inventory of in situ maintained landraces (VNR catalogue) created by the University of Perugia as part of the project "PGR Secure project-Novel characterization of crop wild relative and landrace resources as a basis for improved crop breeding PGR Secure" [41]. The project was funded under the EU Seventh Framework Programme THEME KBBE.2010.1.1-03, Grant agreement no. 266394 (coordinator: Dr. Nigel Maxted; University of Birmingham, UK). This landrace inventory is the result of the work on plant genetic resources carried out by Italian regions and autonomous provinces and reports data available in January 2013 [41]. Dataset: 4806 records.

- The eighteenth revision of Italian Traditional Agri-food Products ("Prodotti Agroalimentari Tradizionali" - PAT) [42] (Decree 30th April 1998, n. 173) created by MiPAAF on 2019 (Decree 7th February 2019, https: / /www.gazzettaufficiale.it/eli/gu/2019/0 3/12/60/so/9/sg/pdf). Dataset: 5149 records.

- The list of Slow Food Presidia (Slow Food Foundation for Biodiversity). The Presidia sustain quality production at risk of extinction, protect unique regions and ecosystems, recover traditional processing methods, and safeguard native breeds and local plant varieties [43] (https:/ / www.fondazioneslowfood.com/en/what-we-do/slow-foodpresidia/). Dataset: 595 records.

- The MiPAAF SIAN (National Agricultural Information System) list of biological seeds database [44] (https:/ / www.sian.it/), containing many landraces that are often used in organic regimes. Only the landraces listed in the European Register of Conservation Varieties were considered. Dataset: 132 records.

- Database of CRC Ge.S.Di.Mont. (Centre of Applied Studies for the Sustainable Management and Protection of Mountain Areas-University of Milan) concerning mountain plant agrobiodiversity [45] (https:/ / www.unimontagna.it/), gathering data from research activities [30,46-49], students' theses, on-field activities interviewing farmers, and bibliographic research. Dataset: 106 records.

- Minor inventories and other sources available online. This category includes farmers' organizations' private lists (i.e., Associazione Antichi Mais Piemontesi, Associazione ROSSO MAIS, etc.) and pro loco associations (i.e., pro loco Fagiolo di Gambolò), NGO newsletters, local farmers' society publications, farm records, and scientific 
literature (including reviews of historical literature, research reports, papers, and articles). Dataset: 95 records.

The above-mentioned inventories and data sources were merged, eliminating overlapping data, and considering only herbaceous plants. Where possible, landrace data were checked so that they corresponded to the characteristics stated by [2]. To understand if the landraces were used for crop production or just preserved/grown by custodian farmers, a web survey regarding cultivation in agricultural holdings was performed for landraces for which no data were present in the databases analyzed.

Data were organized in Excel sheets with different fields: common name/names of the landraces, species/genus, family, elevation, latitude, longitude, municipality, region, cultivator/conservator (farmer/hobbyist and/or farm). Data were organized by botanic families and regions and georeferenced. Geographic coordinates (latitude and longitude) and elevation were acquired through Google Earth and/or Google Maps from the address of the private grower/association/municipality or farm of the specific landrace obtained from the data sources mentioned. Landraces were sorted according to multidimensional scaling (MDS) analysis in order to highlight the main geographical variables that differentiated the samples. MDS was performed using Euclidean distance and considering the latitude, longitude and elevation of each landrace. MDS was performed using the "vegan" package of R 3.5.2 software [50].

Distribution maps of the landraces were created by ArcGIS 10 software (®Esri, Redlands, CA, USA). The same software was used to identify hotspots by the kernel density method [51,52] using the spatial analysis tool. The elevation feature was displayed through boxplots using R software [50]. Boxplots were created by splitting the landraces into families and, for the most numerous (more than 200 landraces), a focus on the main genus and/or species was realized.

The scientific name of each taxon is in accordance with the Portal of Flora of Italy 2020.1 (http:/ / dryades.units.it/floritaly/index.php).

\section{Results and Discussion}

The survey showed that the total number of herbaceous landraces (obtained merging the data of the inventories mentioned in Material and Methods) is 1615, while the National Register currently mentions only 416 varieties, that is, about $26 \%$ of the total varieties observed. This means that the total number of herbaceous Italian landraces identified could increase by about $290 \%$. This information highlights the need to merge all existing databases into the Agrobiodiversity National Register. Although they belong to the same institution (MiPAAF), the Italian Traditional Agri-food Products ("Prodotti Agroalimentari Tradizionali"-PAT) list and the National Register have not yet been merged.

The catalogues created by the Perugia and Milan Universities provided a considerable amount of data, testifying to the success of projects led by research centers, since the survey activity of both was financed by regional, national, or supranational (EU) funds. However, apparently there was a gap in communication towards regional and national institutions since, as mentioned in the introduction, Lombardy (the region in which the University of Milan is located) has not yet communicated any varieties to the bodies in charge of the creation of the National Register. The most complete Italian inventory of landraces can be considered the one derived from the "PGR Secure project" (www.pgrsecure.org) for which the Department of Applied Biology of the University of Perugia compiled "The First Italian Inventory of In Situ Maintained Landraces" [41]. The inventory reported data until January 2013 and accounted for over $20 \%$ of the data collected in this study. Furthermore, the inventory of the Centre of Applied Studies for the Sustainable Management and Protection of Mountain Areas (CRC Ge.S.Di.Mont.) can be considered the most complete for the Alpine center-eastern area [30,46-49].

In Figure 2, the data collected throughout the Italian peninsula are split into families, of which Poaceae, Fabaceae, and Solanaceae are those containing the greatest number of 
landraces. These three families together account for $70 \%$ of all herbaceous landraces, while the remaining families comprise $30 \%$.

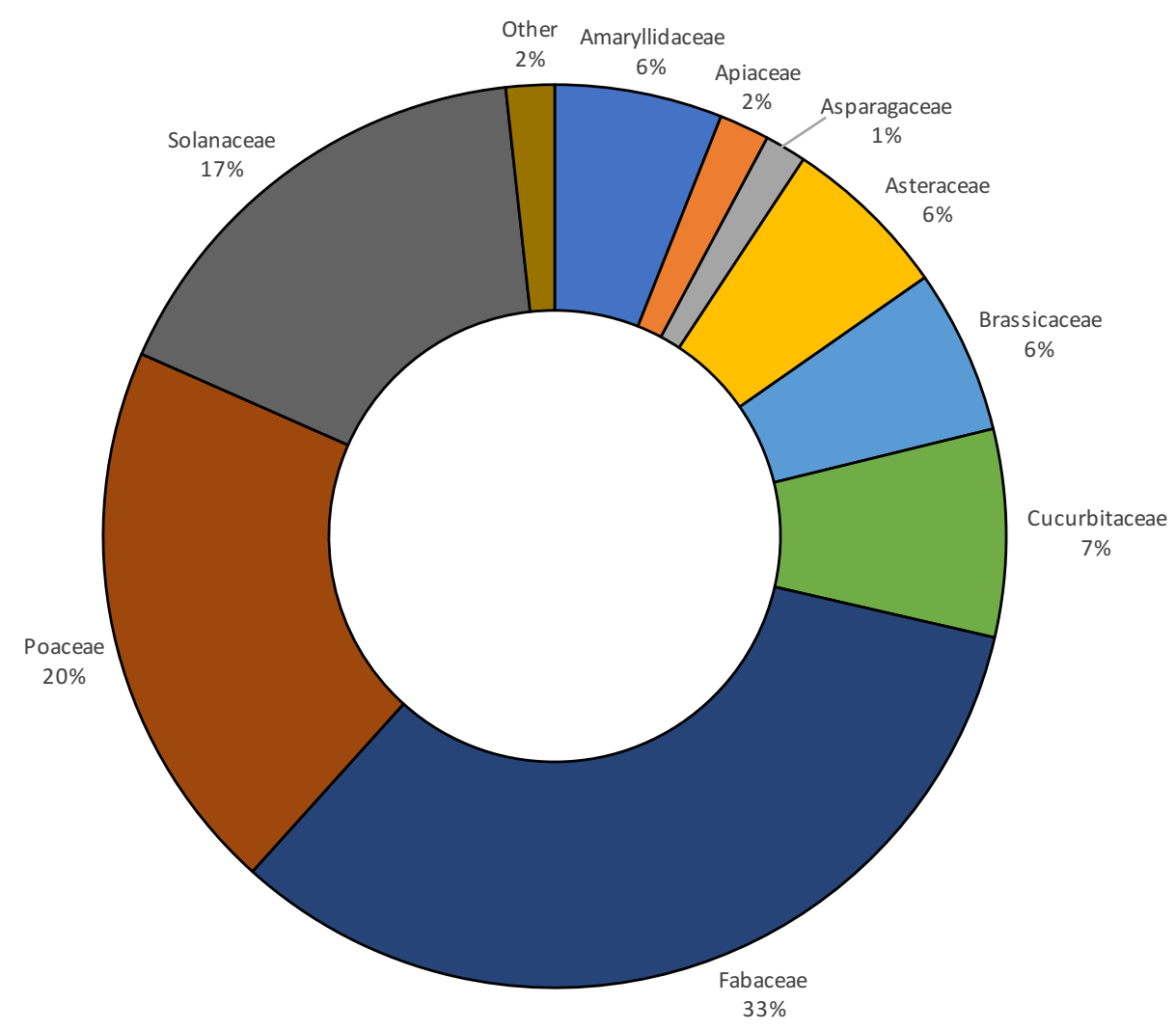

Figure 2. Subdivision of the 1615 herbaceous landraces of Italy according to plant family. "Other" contains Polygonaceae, Chenopodiaceae, Lamiaceae, Plumbaginaceae, Caryophyllaceae, Campanulaceae, and Orobanchaceae families.

This result is coherent with inventories and data collection in other areas of the world. For example, 7 landraces of beans (Phaseolus spp.) and 26 landraces of corn (Zea mays L.) were found in the mountain area of the Arkansas Ozarks (USA), with these two species representing the most numerous plant species among the 39 considered [53]. Likewise, 101 landraces of bean (Phaseolus spp.), 44 of tomatoes (Solanum tuberosum L.), and 28 of corn (Zea mays L.) were found in the Appalachians (North America). Beans, tomatoes, and corn are therefore the most important landraces being maintained across the American highlands [53]. In Portugal, according to the Second Report on the State of the World's Plant Genetic Resources for Food and Agriculture [8], a total of 45,375 accessions were conserved, of which $59.7 \%$ were cereal species and $23.3 \%$ were grain legumes. This is probably linked to the dietary role of these plant resources in providing starch, as regards Poaceae (in particular, corn and wheat) and Solanaceae (potatoes), and proteins, as regards Fabaceae (legumes in general). This is also confirmed by the homogeneous distribution of Fabaceae, Poaceae, and Solanaceae throughout the Italian territory (Figure 3).

Considering, instead, the landraces split into families for each region of Italy (Figure 4), interesting study cases can be observed. For example, only the varieties that can develop at higher altitude such as Fabaceae and Poaceae can be found in Aosta Valley, an almost totally mountainous region, while Sicily is rich in Poaceae landraces, also due to the presence of short-cycle grains (such as the variety "Tumminia") that can grow in the specific conditions of the island, where a second wheat yield can be achieved during the year [54]. In Molise, 50 varieties of beans were identified, contributing greatly to the richness of this family at a national level. 

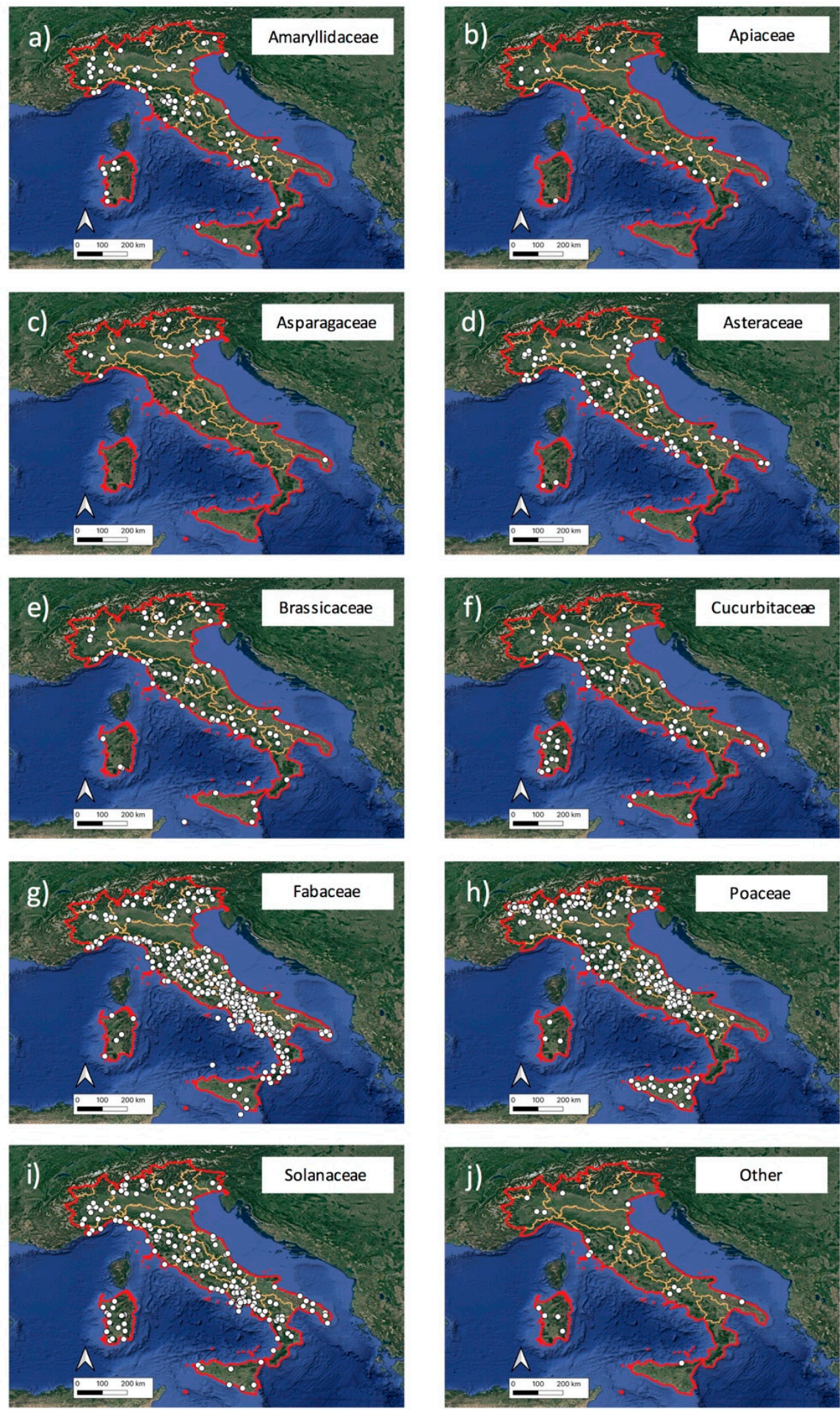

Figure 3. Distribution of the 1615 herbaceous landraces (white dots) in Italy: Amaryllidaceae (a), Apiaceae (b), Asparagaceae (c), Asteraceae (d), Brassicaceae (e), Cucurbitaceae (f), Fabaceae (g), Poaceae (h), Solanaceae (i), landraces of other families (j). The borders of Italy are highlighted in red; those of the Italian regions in yellow. 

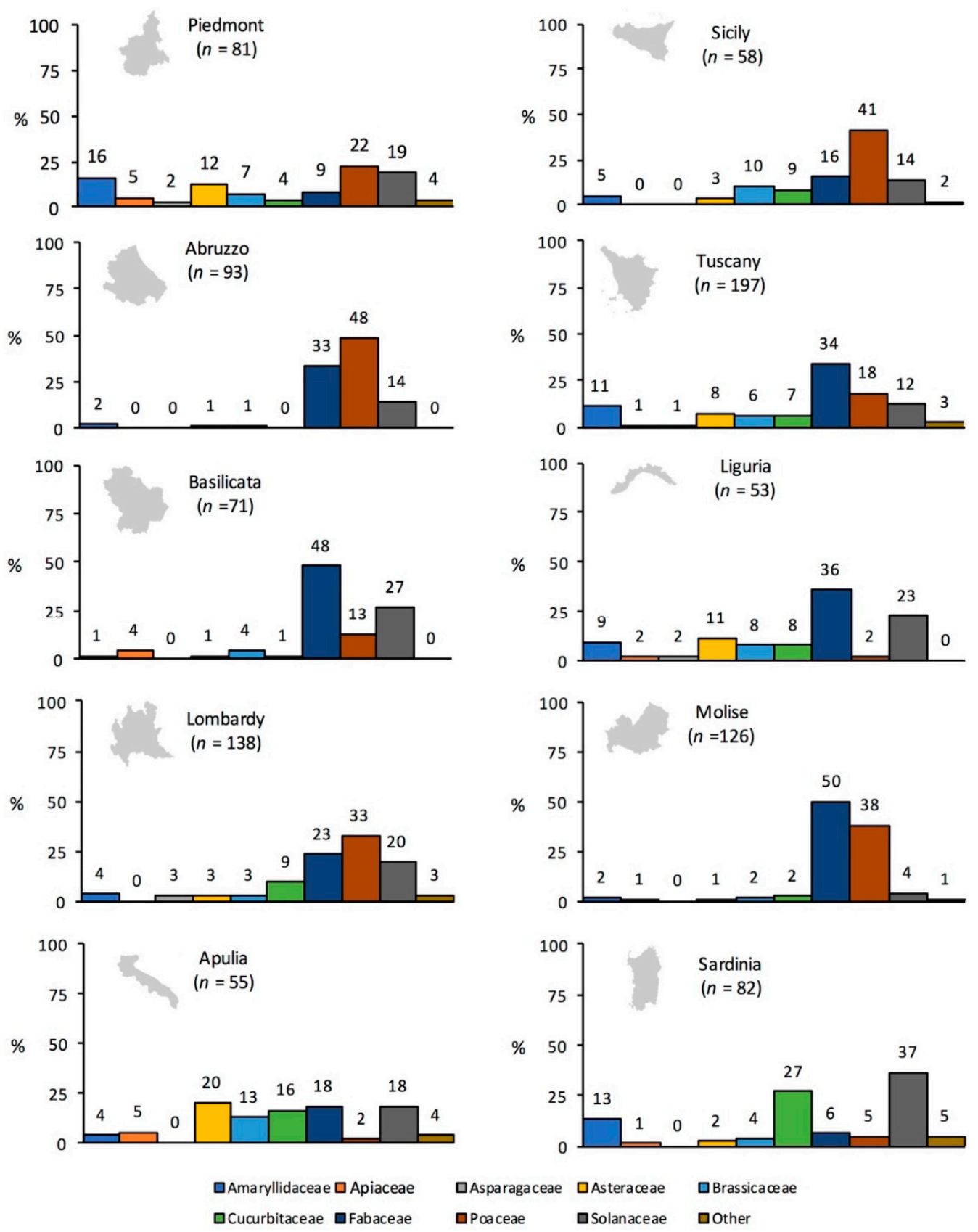

Figure 4. Cont. 

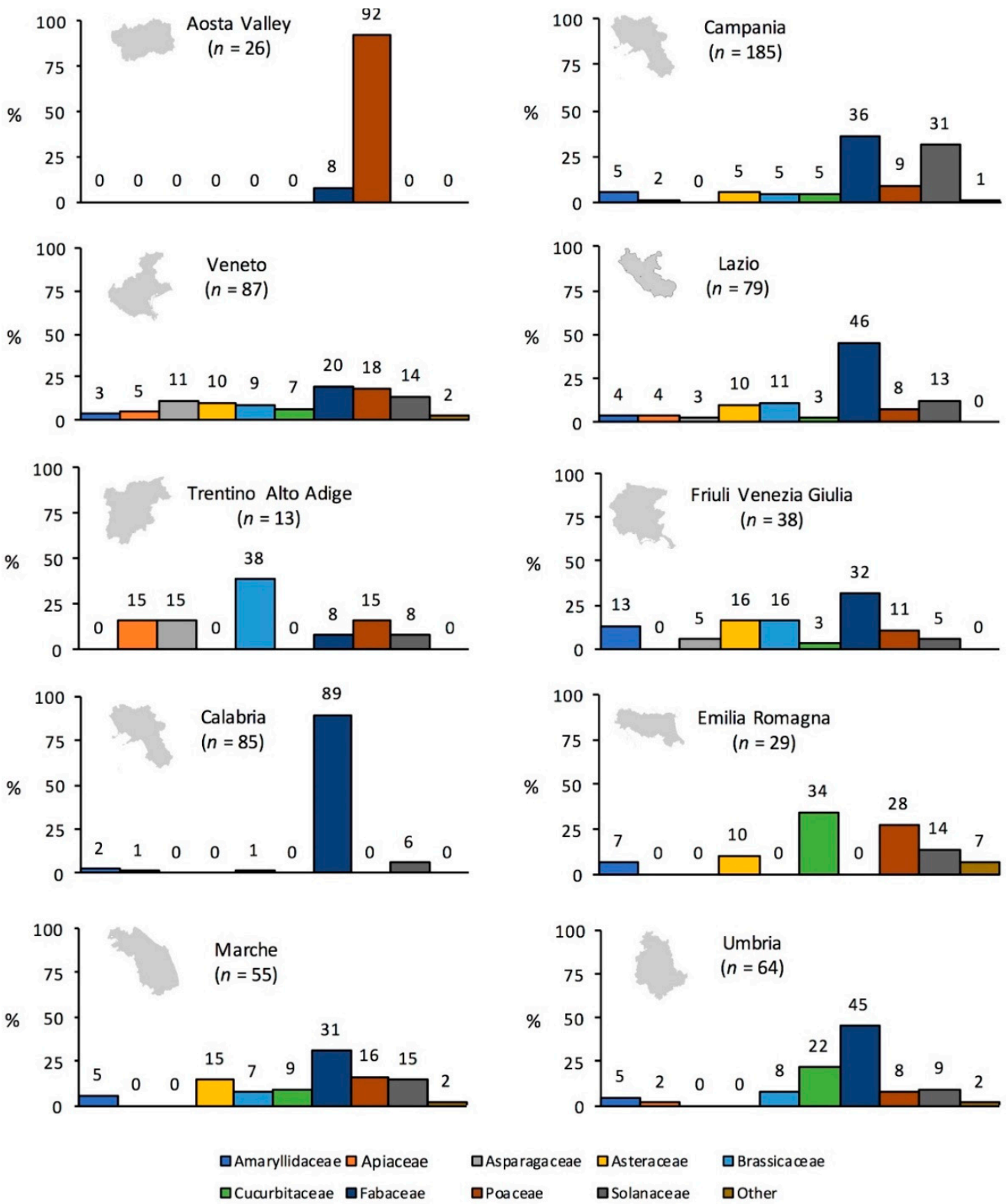

Figure 4. Subdivision of the herbaceous landraces of each Italian region according to plant family.

Apulia, historically considered one of the most important Italian areas for wheat production [55], turned out to be very poor in Poaceae landraces, differently from most of the other Italian regions, probably due to the use of modern commercial varieties with the consequent loss of traditional cultivars. Lombardy, despite being a region characterized by industrialized agriculture in the plains (Po Plain in particular), has preserved many Poaceae, Solanaceae, and Fabaceae thanks to the presence of traditional mountain varieties of Zea mays, Solanum tuberosum, and Phaseolus spp. [30,48,49]. For example, the maize landraces "Spinato di Gandino", "Rostrato Rosso di Rovetta", "Scagliolo di Carenno", "Nero Spinoso", and "Mais delle Fiorine" are good examples of agro-ecotypes of flint maize for "polenta" production developed over the centuries [56]. Landraces of Calabria were almost all included in the Fabaceae family. Emilia Romagna and Sardinia have a high percentage of Cucurbitaceae.

Tuscany is the richest region in herbaceous landraces (197) (Figures 4 and 5), probably due to the unique logistics of the agri-food sector in this region [57], where gastronomic heritage has always been a key factor in touristic success. This region is followed by Campania (185) and Lombardy (138). However, considering the number weighted on the 
surface of the region, Molise was the region with the highest density of landraces and Campania was the second, while Lombardy was tenth (Figure 5). This richness in plant agrobiodiversity of the Molise region and the neighboring Apennine areas (Figures 3 and 5) is probably determined by a variety of environmental and anthropic conditions (such as different bioclimatic levels that reach from sea level to mountain altitudes over a short distance) and agrosystems and related practices distributed among low-input and familybased agriculture [58].
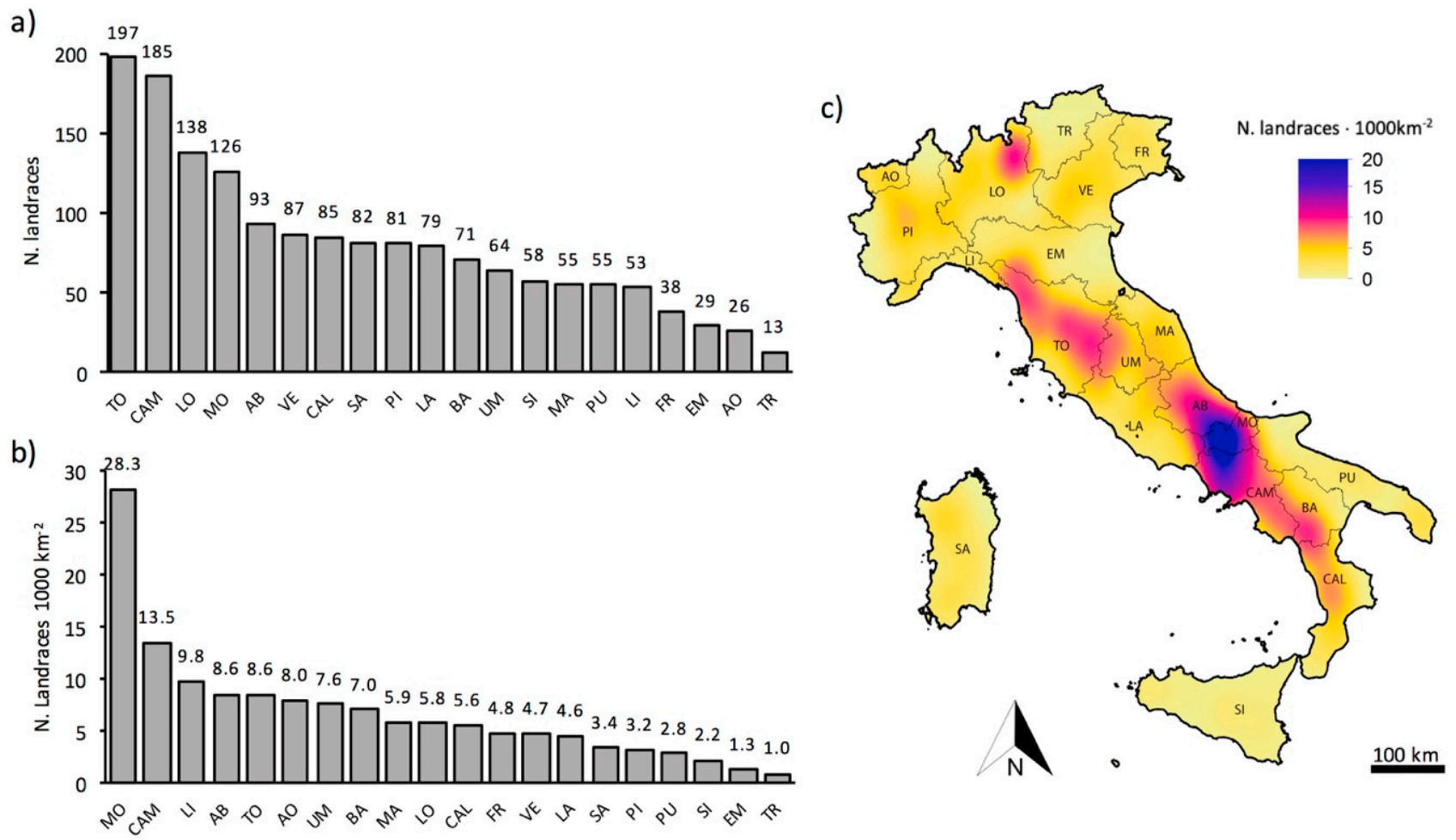

Figure 5. Number of herbaceous landraces (a) and mean number of landraces per $1000 \mathrm{~km}^{2}$ (b) of each Italian region, and maps of landrace hotspots (kernel density) (c). Key: AO, Aosta Valley; PI, Piedmont; LO, Lombardy; TR, Trentino-Alto Adige; VE, Veneto; FR, Friuli-Venezia Giulia; LI, Liguria; EM, Emilia-Romagna; TO, Tuscany; UM, Umbria; MA, Marche; AB, Abruzzo; LA, Lazio; MO, Molise; CAM, Campania; PU, Apulia; BA, Basilicata; CAL, Calabria; SI, Sicily SA, Sardinia.

Apart from a few exceptions, the areas richest in number of landraces and in different crops cultivated as landraces were located inland in hilly and mountainous areas of the Apennine chain that are characterized by high environmental diversity. The Apennines is a land system that preserves, and in some case enhances, the biological diversity threatened by changes in land use and by diffuse abandonment [58,59].

As can be observed in the map in Figure 5, some areas (Apennines of Molise, Abruzzo, Campania, and Calabria, the Central Apennines of Tuscany, Umbria, and Emilia-Romagna, and Central Eastern Alps on the border between Lombardy and Trentino-Alto-Adige) can be considered "hotspots" of herbaceous landraces and this may be linked to an anthropical explanation, such as the existence of research and inventory initiatives (as already explained for the case of the VNR catalogue [41] or CRC Ge.S.Di.Mont. [30,46-49,56] or due to the existence of particularly active farmers' associations). Agricultural and environmental conditions obviously also contributed to this phenomenon. In the research found in [60], in fact, areas with a high level of agrobiodiversity in which to set or enhance in situ conservation of plant genetic resources (most appropriate areas (MAPAs)) were identified through a methodological approach using three criteria: presence of landrace diversity, presence of wild species, and agroecosystem ecological diversity. Considering their additive strategy (AS), it is not surprising that they match the hotspots identified. 
The MDS biplot (Figure 6) shows that along the first axis (MDS1), which accounts for $98.34 \%$ of the total variance in the dataset, the samples are sorted by elevation (which increases along the MDS1).

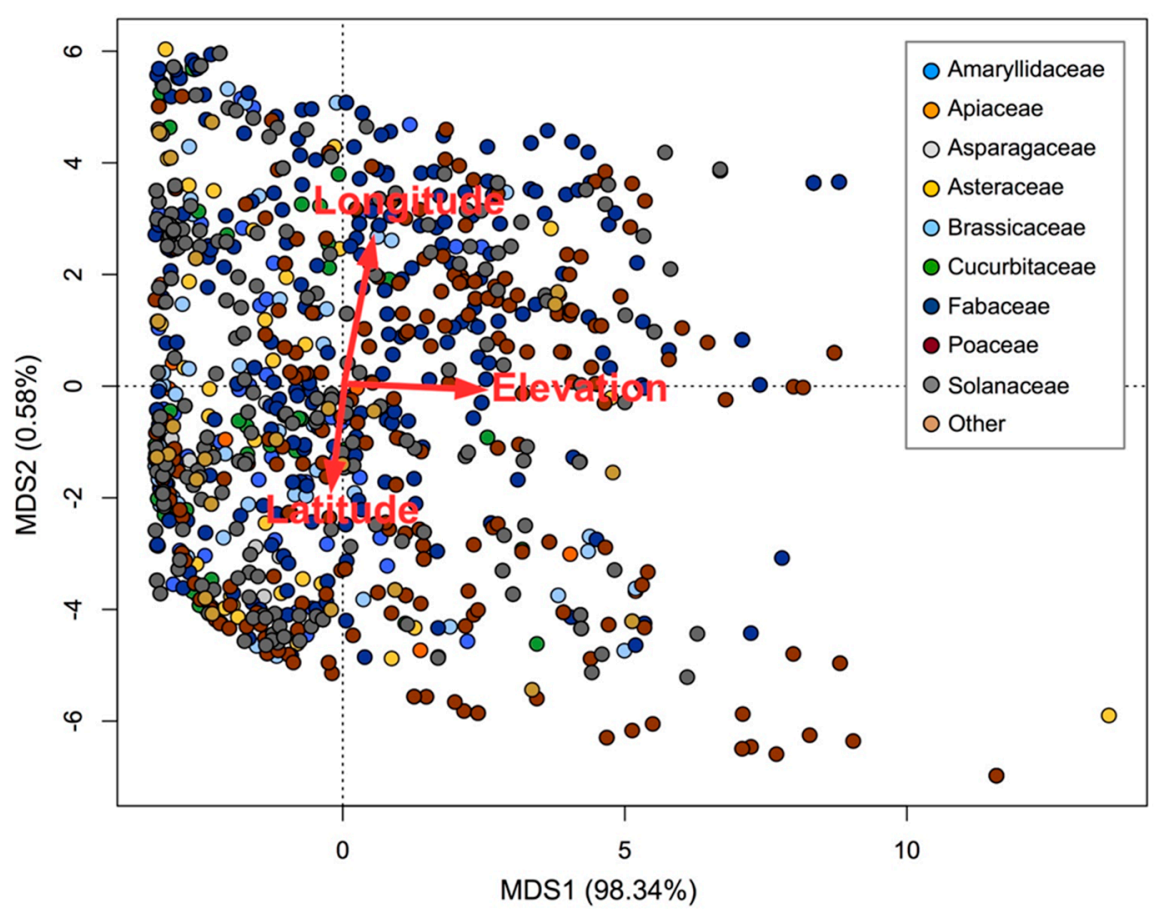

Figure 6. Multidimensional scaling (MDS) ordination biplot of herbaceous landraces associated with geographical (latitude, longitude, and elevation) variables.

Landraces are concentrated in the sub-mountain, hilly, and foothill areas, while there are only a few cases in the great industrial plains (Figures 3 and 7). Comparing Figures 2,6 and 7, it is clear that the families that contribute most to the number of landraces (Fabaceae, Poaceae, and Solanaceae) are those containing landraces cultivated in a wide altitudinal range (from sea level to over $1000 \mathrm{~m}$ a.s.1.) but concentrated in hilly and sub-mountain areas (150-800 $\mathrm{m}$ a.s.1.). This is due to the fact that these families contain plants adaptable to, and grown in, these environments, such as beans (Phaseolus spp.), rye (Secale cereale), potatoes (Solanum tuberosum), and barley (Hordeum spp.) [48,61-63]. As shown by this study, most of the landraces that are part of the Fabaceae family are cultivated in hilly and sub-mountain areas and $70 \%$ are beans (Figure 8 ). Moreover, most of the Poaceae landraces (excluding rice landraces) are cultivated in hilly and sub-mountain areas, especially rye landraces, while as regards the Solanaceae family, only potato landraces (25\% of all Solanaceae) are mostly grown from 300 to $1200 \mathrm{~m}$ a.s.l. (Figure 8). Very few landraces are grown over $1500 \mathrm{~m}$ a.s.l. because at the highest elevations, anthropic activities (such as agriculture) are very limited due to the harsh climatic conditions. 


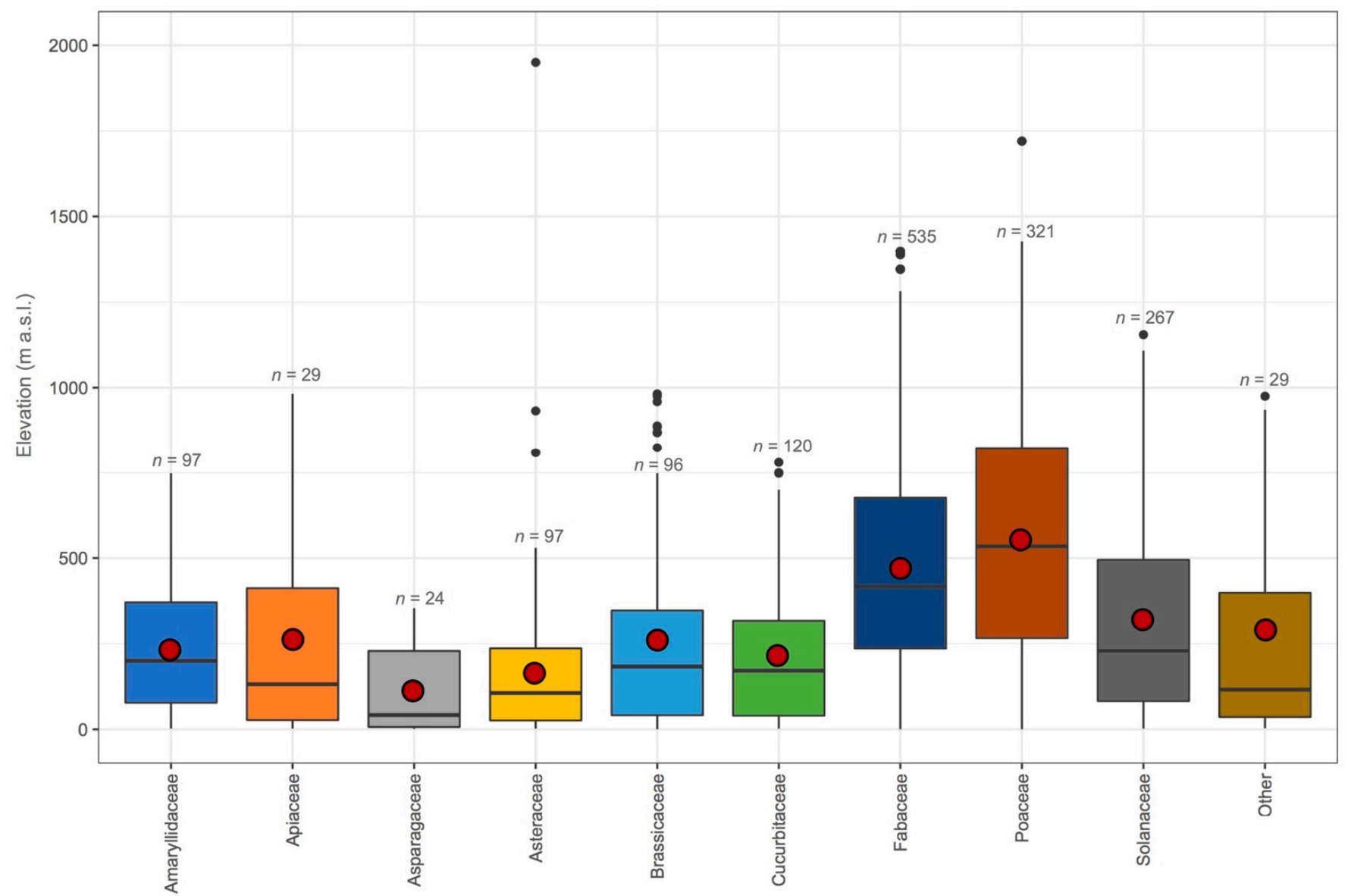

Figure 7. Boxplots of elevation distribution of landrace families. For each boxplot, mean (red dot) and median (black line) are highlighted. Poaceae, Fabaceae, and Solanaceae account for $70 \%$ of the herbaceous landraces of Italy. Outliers are shown with black dots.

Therefore, as for many other areas of the planet [53,61,64-66], mountainous and hilly territories represent hotspots of plant agrobiodiversity in Italy. This is firstly linked to the remoteness of such areas compared to the great plains (such as the Po Plain), where highly productive commercial varieties or hybrids are grown. The particular environmental conditions of hilly and mountain areas and difficulties in communication have guaranteed that cultivars specifically adapted to those territories developed, becoming landraces. At the same time, in the great industrialized areas (which are generally located in the plains), commercial cultivars rapidly substituted traditional cultivars, resulting in the disappearance of traditional agricultural systems and the knowledge associated with landrace development, maintenance, management, and use, an occurrence reported in many parts of the world [67]. However, it should be noted that small islands often show a remarkable wealth of landraces together with traditional methods of agriculture and horticulture, and, even if this is not clear from the kernel density map, they are worth mentioning as agrobiodiversity spots, particularly as regards the crop wild relatives, as can be seen from previous studies in Italy $[68,69]$. This is probably due to the same reasons as for mountain and hilly areas (neglection, isolation, and traditional rural methods) and can be observed in small islands belonging to very different climatic fascia, for example, the case of the Outer Hebridean islands of Western Scotland highlighted in research for the UK national landrace inventory [70]. Sometimes, we can find convergent situations, where a small island is also a mountain territory with a high number of not easily accessible small villages, as in the cases of Sicily, Sardinia, and Corsica. An exploratory mission in the latter collected more than 112 valuable landraces, belonging to several species of pulses, vegetables, cereals, forages, spices, and condiments [71]. 
a)

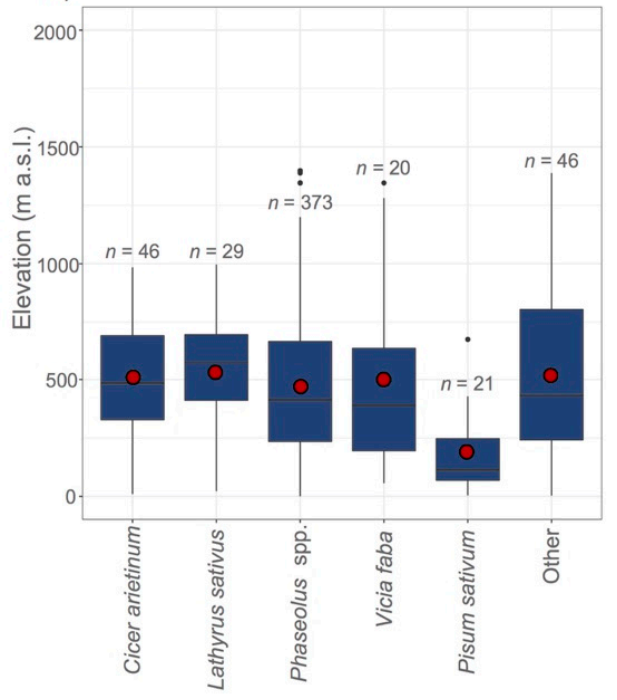

b)

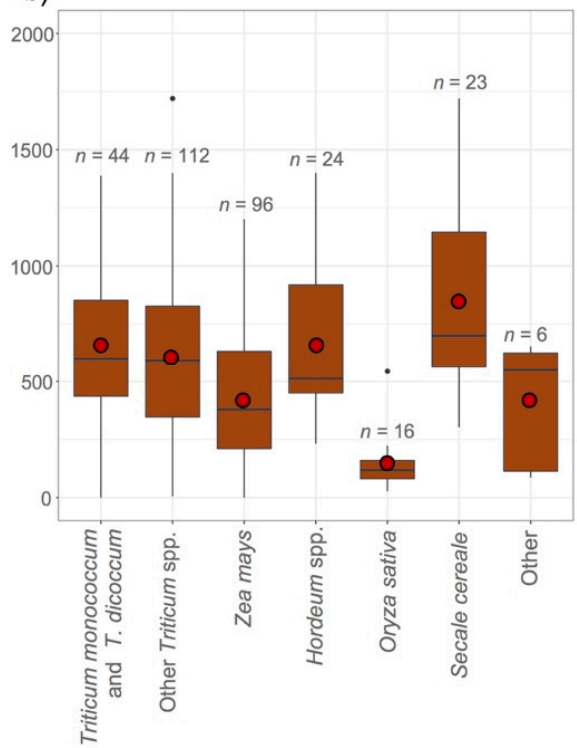

c)

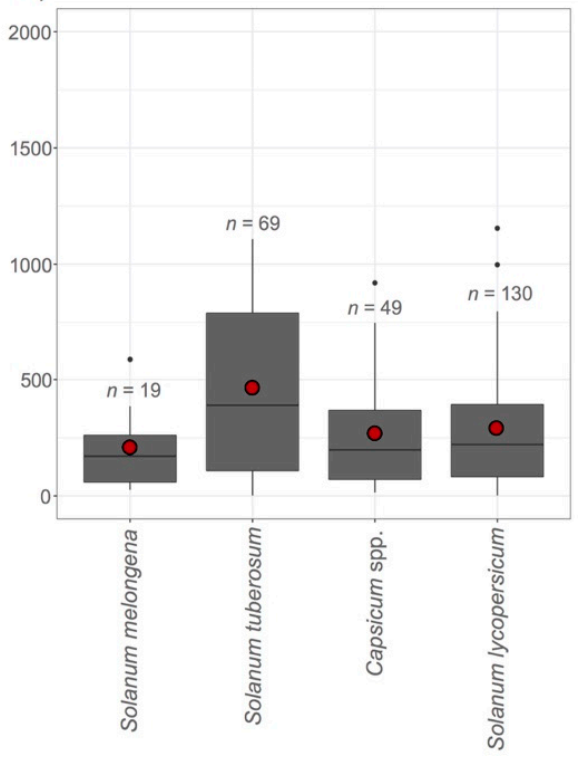

Figure 8. Boxplots of elevation distribution of the main genus/species of Fabaceae (a), Poaceae (b), and Solanaceae (c) landraces. For each boxplot, mean (red dot) and median (black line) are highlighted. Outliers are shown with black dots.

In general, the absence of detailed knowledge on agrobiodiversity prevents the application of methodological tools that could successfully assist in biodiversity conservation, and inventories are a first step to assessing biodiversity richness and distribution patterns and monitoring changes [36]. Concomitantly, the conservation of agroecosystems and traditional farming methods together with the protection of buffer areas of biodiversity such as dry walls, green infrastructures, and ecotone belts (and other typologies of habitat defined by directive $92 / 43$ ECC) can guarantee the conservation of a high level of biodiversity and the conservation of species also including crop wild relatives.

The data contained in the National Register must be considered the "official" data on Italian agrobiodiversity, since this is the tool by which the Italian government implemented European Community guidelines on agrobiodiversity conservation. The data reflect the situation globally, as it is recognized that, worldwide, our knowledge of biodiversity includes only $20 \%$ of the total estimated number of species [36]. Coordination of the stakeholders in charge of agrobiodiversity conservation and study therefore appears fundamental.

As shown by this study, marginal territories such as mountain and hilly areas are hotspots of agrobiodiversity (confirming the data of the few studies conducted in Italian provinces/regions $[30,60,72]$ ), and these areas are, today, subject to climatic and anthropic imbalances. The reasons that led to the abandonment of mountain landraces are many but are mainly linked to the abandonment of mountain areas by human beings. This phenomenon has intensified in the Alps since the middle of the last century and is still in progress [36,73-78]. The abandonment of mountain areas (and related agricultural practices) has caused changes to the landscape (loss of agricultural land due to the expansion of forests), imbalances to ecosystems (increase in susceptibility to hydrogeological instability phenomena), and the loss of agrobiodiversity and all it involves (typical dishes, traditions, and popular culture linked to agriculture) [48]. It is therefore of paramount importance to reverse this trend to preserve this heritage through the characterization (agronomic, genetic, nutritional, and historical) of landraces and the promotion of sustainable, innovative, and quality agri-food chains [30] other than the conservation in seed banks $[79,80]$. These actions should be implemented as soon as possible to avoid the loss of such resources, as, from our survey, only $33.4 \%$ of landraces are grown by professional farmers, while the remaining $(66.6 \%)$ are grown by hobbyist farmers. 


\section{Conclusions}

This research contributed to knowledge on herbaceous landraces cultivated (preserved in situ) in Italy by merging the most important databases. The study allowed the creation of an updated database of 1615 herbaceous landrace varieties, meaning that the total number of Italian herbaceous landraces identified could increase by about $290 \%$. Their distribution throughout Italy was analyzed (considering single regions), highlighting interesting regional differences and locating herbaceous landrace hotspots, situated mainly in the hilly and sub-mountain marginal areas of Italy.

Parallels can be drawn between the Italian situation and the hilly, sub-mountain, and, in general, marginal areas (such as small islands and archipelagos) that can be considered hotspots of agrobiodiversity and require scientific attention for the protection of biodiversity and agrobiodiversity. Data on the latter, in particular horticultural and herbaceous agrobiodiversity, particularly at risk due to its characteristics, need merging and analyzing as inventories as the first step towards the study, conservation, and promotion of agrobiodiversity.

It is to be hoped that the dataset of this research, currently the most comprehensive and updated available in Italy, will be useful to all stakeholders (civil society, farmers, and governance as well as researchers) as it provides information on Italian herbaceous landraces and can be a starting point to enrich the Agrobiodiversity National Register and trigger actions of characterization, protection, and promotion of these resources. For these purposes, the data gathered during the research work will be forwarded to the Department for Regional Affairs and Autonomies (DARA) of the Italian Presidency of the Council of Ministers. Furthermore, an online interactive map reporting the main information regarding each landrace will be available open source at the following link: https://www.unimontagna.it/servizi/mappatura-agrobiodiversita-vegetale/. It is also to be hoped that, in the future, the database will be supplemented with maintainer details, cultivation, usage, and specific threats and that information will be made available via a web-enabled database and periodically updated to monitor changes in on-farm maintained landrace diversity following the recommendations of [40].

Author Contributions: Conceptualization, L.G. and A.G.; methodology, L.G., D.P. and V.L.; validation, L.G. and A.G.; formal analysis, L.G. and D.P.; investigation, L.G., D.P., V.L. and A.R.; data curation, L.G., D.P., V.L. and A.R.; writing—original draft preparation, L.G. and V.L.; writing—review and editing, L.G. and V.L.; supervision, A.G.; project administration, L.G. and A.G.; funding acquisition, L.G. and A.G. All authors have read and agreed to the published version of the manuscript.

Funding: This research was supported by the Department for Regional Affairs and Autonomies (DARA) of the Italian Presidency of the Council of Ministers (DARA-CRC Ge.S.Di.Mont. agreement), FISR-MIUR “Italian Mountain Lab" project, and by the "Montagne: Living Labs di innovazione per la transizione ecologica e digitale" project.

Institutional Review Board Statement: Not applicable.

Informed Consent Statement: Not applicable.

Data Availability Statement: The data presented in this study are openly available here: https: //www.unimontagna.it/servizi/mappatura-agrobiodiversita-vegetale/.

Acknowledgments: We would like to thank Giulia Ceciliani for help provided in collecting and analyzing data, Vincenzo Montalbano and Maurizio D'Aristotile of MiPAAF for their collaboration and information relating to the Agrobiodiversity National Register, Francesco Tufarelli of DARA for supporting this research, and Justine Crellin for the English editing.

Conflicts of Interest: The authors declare no conflict of interest. 


\section{References}

1. Perrino, E.V.; Perrino, P. Crop wild relatives: Know how past and present to improve future research, conservation and utilization strategies, especially in Italy: A review. Genet. Resour. Crop Evol. 2020, 67, 1067-1105. [CrossRef]

2. Camacho Villa, T.C.; Maxted, N.; Scholten, M.; Ford-Lloyd, B. Defining and identifying crop landraces. Plant Genet. Res. 2005, 3, 373-384. [CrossRef]

3. Yadav, O.P.; Bidinger, F.R. Utilization, diversification and improvement of landraces for enhancing pearl millet productivity in arid environments. Ann. Arid Zone 2007, 46, 49-57.

4. Ceccarelli, S. Landraces: Importance and use in breeding and environmentally friendly agronomic systems. In Agrobiodiversity Conservation: Securing the Diversity of Crop Wild Relatives and Landraces; Maxted, N., Ehsan Dulloo, M., Ford-Lloyd, B.V., Frese, L., Iriondo, J.M., Pinheiro de Carvalho, M.A.A., Eds.; CAB International: Oxfordshire, UK, 2012; pp. 103-117.

5. Puglisi, D.; Landoni, M.; Cassani, E.; Toschi, I.; Lucchini, G.; Cesari, V.; Borlini, G.; Scapin, A.; Pilu, R. Traditional farmers' varieties: A valuable source of genetic variability for biofortification programs. Maydica 2018, 63, 1-10.

6. Frison, E.A.; Cherfas, J.; Hodgkin, T. Agricultural biodiversity is essential for a sustainable improvement in food and nutrition security. Sustainability 2011, 3, 238-253. [CrossRef]

7. FAO. Building on Gender, Agrobiodiversity and Local Knowledge; Food and Agriculture Organization of the United Nations: Rome, Italy, 2004.

8. FAO. Second Report on the State of the World's Plant Genetic Resources for Food and Agriculture. Commission on Genetic Resources for Food and Agriculture; Food and Agriculture Organization of the United Nations: Rome, Italy, 2010.

9. Hammer, K.; Knüppfer, H.; Xhuveli, L.; Perrino, P. Estimating genetic erosion in landraces-Two case studies. Genet. Resour. Crop Evol. 1996, 43, 329-336. [CrossRef]

10. FAO. Agricultural biodiversity. Background Paper 1. In Proceedings of the FAO/Netherlands Conference: "The Multifunctional Character of Agriculture and Land", Maastricht, The Netherlands, 12-17 September 1999.

11. Rischkowsky, B.; Pilling, D. The State of the World's Animal Genetic Resources for Food and Agriculture—In Brief; Food and Agriculture Organization of the United Nations: Rome, Italy, 2007.

12. Esquinas-Alcázar, J. Protecting crop genetic diversity for food security: Political, ethical and technical challenges. Nature 2010, 6, 946-953. [CrossRef]

13. CBD (Convention on Biological Diversity). Convention on Biological Diversity: Text and Annexes; Secretariat of the Convention on Biological Diversity: Montreal, QC, Canada, 1992.

14. CBD (Convention on Biological Diversity). Global Strategy for Plant Conservation; Secretariat of the Convention on Biological Diversity: Montreal, QC, Canada, 2002.

15. CBD (Convention on Biological Diversity). Conference of the Parties 10 Decision X/17. Consolidated Update of the Global Strategy for Plant Conservation 2011-2020; Secretariat of the Convention on Biological Diversity: Montreal, QC, Canada, 2010.

16. Bragdon, S. The convention on biological diversity. Glob. Environ. Chang. 1996, 6, 177-179. [CrossRef]

17. Paton, A.J.; Brummitt, N.; Govaerts, R.; Harman, K.; Hinchcliffe, S.; Allkin, B.; Lughadha, E.N. Target 1 of the global strategy for plant conservation: A working list of all known plant species progress and prospects. Taxon 2008, 57, 602-611.

18. FAO. International Treaty on Plant Genetic Resources for Food and Agriculture; Food and Agriculture Organization of the United Nations: Rome, Italy, 2009.

19. Sharrock, S.; Oldfield, S.; Wilson, O. Plant Conservation Report 2014: A Review of Progress in Implementation of the Global Strategy for Plant Conservation 2011-2020; CBD Technical Series 81; Secretariat of the Convention on Biological Diversity: Montréal, QC, Canada; Botanic Gardens Conservation International: Richmond, UK, 2014.

20. EU Commission. EUROPE 2020 A Strategy for Smart, Sustainable and Inclusive Growth. 2010. Available online: https: / / eurlex.europa.eu/legal-content/EN/TXT/?uri=CELEX\%3A52010DC2020 (accessed on 11 September 2020).

21. United Nations. Transforming Our World: The 2030 Agenda for Sustainable Development. 2015. Available online: https: / / undocs.org/A/RES/70/1 (accessed on 11 September 2020).

22. EU Commission. Commission Directive 2008/62/EC of 20 June 2008 Providing for Certain Derogations for Acceptance of Agricultural Landraces and Varieties Which Are Naturally Adapted to the Local and Regional Conditions and Threatened by Genetic Erosion and for Marketing of Seed and Seed Potatoes of Those Landraces and Varieties. Available online: https: / / eur-lex.europa.eu/legal-content/EN/ALL/?uri=CELEX\%3A32008L0062 (accessed on 1 September 2020).

23. EU Commission. Commission Directive 2009/145/EC of 26 November 2009 Providing for Certain Derogations, for Acceptance of Vegetable Landraces and Varieties Which Have Been Traditionally Grown in Particular Localities and Regions and Are Threatened by Genetic Erosion and of Vegetable Varieties with no Intrinsic Value for Commercial Crop Production but Developed for Growing under Particular Conditions and for Marketing of Seed of Those Landraces and Varieties. Available online: https:/ / eur-lex.europa.eu/legal-content/EN/TXT/?uri=CELEX\%3A32009L0145 (accessed on 1 September 2020).

24. EU Commission. Commission Directive 2010/60/EU of 30 August 2010 Providing for Certain Derogations for Marketing of Fodder Plant Seed Mixtures Intended for Use in the Preservation of the Natural Environment Text with EEA Relevance. Available online: https:/ / eur-lex.europa.eu/legal-content/EN/ (accessed on 15 September 2020).

25. Spataro, G.; Negri, V. The European seed legislation on conservation varieties: Focus, implementation, present and future impact on landrace on farm conservation. Genet. Resour. Crop. Evol. 2013, 60, 2421-2430. [CrossRef]

26. Bocci, R. Seed Legislation and agrobiodiversity: Conservation varieties. J. Agric. Environ. Int. Dev. 2009, 103, 31-49. 
27. Italian Republic. Law 2015/194 (2015) Disposizioni per la Tutela e la Valorizzazione della Biodiversità di Interesse Agricolo e Alimentare. Available online: https:/ /www.gazzettaufficiale.it/eli/gu/2015/12/11/288/sg/pdf (accessed on 15 September 2020).

28. Hammer, K.; Laghetti, G. Genetic Erosion-Examples from Italy. Genet. Resour. Crop. Evol. 2005, 52, 629-634. [CrossRef]

29. MiPAAF Ministerial Decree 2019/39407. Available online: https:/ / rica.crea.gov.it/APP/anb / (accessed on 15 September 2020).

30. Giupponi, L.; Pilu, R.; Scarafoni, A.; Giorgi, A. Plant agro-biodiversity needs protection, study and promotion: Results of research conducted in Lombardy region (Northern Italy). Biodivers. Conserv. 2020, 29, 409-430. [CrossRef]

31. Negri, V. Landraces in central Italy: Where and why they are conserved and perspectives for their on-farm conservation. Genet. Resour. Crop Evol. 2003, 50, 871-885. [CrossRef]

32. Zeven, A.C. Landraces: A review of definitions and classifications. Euphytica 1998, 104, 127-139. [CrossRef]

33. MiPAAF. Linee Guida per la Conservazione e la Caratterizzazione della Biodiversità Vegetale, Animale e Microbica di Interesse per l'Agricoltura. Piano Nazionale sulla Biodiversità di Interesse Agricolo; INEA: Roma, Italy, 2013.

34. Montesano, V.; Negro, D.; Sarli, G.; Logozzo, G.; Spagnoletti Zeuli, P. Landraces in Inland areas of the Basilicata region, Italy: Monitoring and perspectives for on farm conservation. Genet. Resour. Crop Evol. 2012, 59, 701-716. [CrossRef]

35. European Commission. EU COM 380, 20.5.2020. Communication from the Commission to the European Parliament, the Council, the European Economic and Social Committee and the Commettee of the Regions: EU Biodiversity Strategy for 2030. Bringing Nature Back into Our Lives. Available online: https: / ec.europa.eu/info/sites/info/files/communication-annex-eubiodiversity-strategy-2030_en.pdf (accessed on 23 September 2020).

36. de Carvalho, M.Â.A.P.; Bebeli, P.J.; Barata da Silva, A.M.; Bettencourt, E.; Slaski, J.J.; Dias, S. Agrobiodiversity: The Importance of Inventories in the Assessment of Crop Diversity and Its Time and Spatial Changes. In Genetic Diversity and Erosion in Plants Case Histories; Ahuja, M.R., Mohan Jain, S., Eds.; Sustainable Development and Biodiversity; Springer International Publishing: Frankfurt, Switzerland, 2016; Volume 2, pp. 307-335.

37. Frese, L.; Reinhard, U.; Bannier, H.-J.; Germeier, C.U. Landrace Inventory in Germany-Preparing the National Implementation of the EU Directive 2008/62/EC. In European Landraces on-Farm Conservation Management Use; Negri, V., Raggi, L., Maxted, N., Eds.; University of Perugia: Perugia, Italy, 2019; pp. 79-96.

38. Krasteva, L. Collection and evaluation of local vegetable genetic resources in Bulgaria. Acta Hortic. 2007, 729, 73-76. [CrossRef]

39. Teklu, Y.; Hammer, K. Farmers' Perception and Genetic Erosion of Tetraploid Wheats Landraces in Ethiopia. Genet. Resour. Crop. Evol. 2006, 53, 1099-1113. [CrossRef]

40. Maxted, N.; Veteläinen, M.; Negri, V. Landrace Inventories: Needs and Methodologies. In European Landraces on-Farm Conservation Management Use; Negri, V., Raggi, L., Maxted, N., Eds.; University of Perugia: Perugia, Italy, 2019; pp. 45-68.

41. Negri, V.; Donnini, D.; Gigante, D.; Landucci, F.; Pacicco, L.; Panella, L.; Torricelli, R.; Venanzoni, R. The First Italian Inventory of In Situ Maintained Landraces. 2013. Available online: http://vnr.unipg.it/PGRSecure/html/national_inventory.html (accessed on 24 September 2020).

42. MiPAAF. Decreto Legislativo Decreto 7 Febbraio 2019. Available online: https://www.gazzettaufficiale.it/eli/gu/2019/03/12/6 $0 / \mathrm{so} / 9 / \mathrm{sg} / \mathrm{pdf}$ (accessed on 24 September 2020).

43. Slow Food List of Presidia. Available online: https://www.fondazioneslowfood.com/en/what-we-do/slow-food-presidia/ (accessed on 24 September 2020).

44. MiPAAF. SIAN List of Biological Seeds Database. Available online: https:/ / www.sian.it/ (accessed on 24 September 2020).

45. CRC Ge.S.Di.Mont. Landraces Database. Available online: https://www.unimontagna.it/ (accessed on 24 September 2020).

46. Giupponi, L.; Ceciliani, G.; Leoni, V.; Panseri, S.; Pavlovic, R.; Lingua, G.; Di Filippo, A.; Giorgi, A. Quality traits of saffron produced in Italy: Geographical area effect and good practices. J. Appl. Bot. Food Qual. 2019, 92, 336-342.

47. Giupponi, L.; Borgonovo, G.; Panseri, S.; Giorgi, A. Multidisciplinary study of a little-known landrace of Fagopyrum tataricum Gaertn. of Valtellina (Italian Alps). Genet. Resour. Crop Evol. 2019, 66, 783-796. [CrossRef]

48. Giupponi, L.; Tamburini, A.; Giorgi, A. Prospects for broader cultivation and commercialization of copafam, a local variety of Phaseolus coccineus L., in the Brescia pre-Alps. Mt. Res. Dev. 2018, 38, 24-34. [CrossRef]

49. Cassani, E.; Cantaluppi, E.; Landoni, M.; Giupponi, L.; Giorgi, A.; Pilu, R. Genetic studies regarding the control of seed pigmentation of an ancient European pointed maize (Zea mays L.) rich in Phlobaphenes: The "Nero Spinoso" from the Camonica valley. Genet. Resour. Crop Evol. 2017, 64, 761-773. [CrossRef]

50. R Development Core Team. R: A Language and Environment for Statistical Computing; R Foundation for Statistical Computing: Vienna, Austria, 2018. Available online: http:/ / www.r-project.org (accessed on 1 September 2020).

51. Silverman, B.W. Density Estimation for Statistics and Data Analysis; Chapman and Hall: New York, NY, USA, 1986.

52. Janssen, P.; Swanepoel, J.; Veraverbeke, N. A note on the behaviour of a kernel-smoothed kernel density estimator. Stat. Probab. Lett. 2020, 158, 108663. [CrossRef]

53. Veteto, J.R. Seeds of persistence: Agrobiodiversity in the American Mountain South. Cult. Agric. Food Environ. 2014, 36, 17-27. [CrossRef]

54. Alfeo, V.; Jaskula-Goiris, B.; Venora, G.; Schimmenti, E.; Aerts, G.; Todaro, A. Screening of durum wheat landraces (Triticum turgidum subsp. durum) for the malting suitability. J. Cereal Sci. 2018, 83, 101-109. [CrossRef]

55. Russo, S. Puglia. In Italian Historical Rural Landscapes; Agnoletti, M., Ed.; Environmental History; Springer: Dordrecht, The Netherlands, 2013; Volume 1, pp. 154-196. 
56. Giupponi, L.; Leoni, V.; Colombo, F.; Cassani, E.; Hejna, M.; Rossi, L.; Pilu, R. Characterization of “Mais delle Fiorine" (Zea mays L.) and nutritional, morphometric and genetic comparison with other maize landraces of Lombardy region (Northern Italy). Genet. Resour. Crop Evol. 2021. [CrossRef]

57. Malevolti, I. Logistica del settore agroalimentare in Toscana. In Proceedings of the Atti dell'Accademia dei Georgofili, Firenze, Italy, 29 May 2012; Polistampa: Firenze, Italy, 2012; Volume 9. Serie VIII, Tomo II.

58. Farina, A. Upland farming systems of the Northern Apennines. In Conserving Biodiversity Outside Protected Areas. The Role of Traditional Agro-Ecosystems; Halladay, P., Gilmour, D.A., Eds.; IUCN: Gland, Switzerland; Cambridge, UK, 1995; pp. 123-130.

59. Rac, I.; Juvančič, L.; Erjavec, E. Stimulating collective action to preserve High Nature Value farming in post-transitional settings. A comparative analysis of three Slovenian social-ecological systems. Nat. Conserv. 2020, 39, 87-111. [CrossRef]

60. Pacicco, L.; Bodesmo, M.; Torricelli, R.; Negri, V.A. Methodological approach to identify agro-biodiversity hotspots for priority in situ conservation of plant genetic resources. PLoS ONE 2018, 13, e0197709. [CrossRef] [PubMed]

61. Akhalkatsi, M.; Otte, A.; Togonidze, N.; Bragvadze, T.; Asanidze, Z.; Arabuli, G.; Chikhelidze, N.; Mazanishvili, L. Agrobiodiversity and genetic erosion of crop varieties and plant resources in the Central Great Caucasus. Ann. Agrar. Sci. 2017, 15, 11-16. [CrossRef]

62. Peratoner, G.; Seling, S.; Klotz, C.; Florian, C.; Figl, U.; Schmitt Genet, A.O. Variation of agronomic and qualitative traits and local adaptation of mountain landraces of winter rye (Secale cereale L.) from Val Venosta/Vinschgau (South Tyrol). Genet. Resour. Crop Evol. 2016, 63, 261-273. [CrossRef]

63. Giupponi, L.; Leoni, V.; Pedrali, D.; Ceciliani, G.; Bassoli, A.; Borgonovo, G. Morphometric and phytochemical characterization and elevation effect on yield of three potato landraces of the Ligurian Apennines (Northern Italy). J. Appl. Bot. Food Qual. 2020, 93, 234-243.

64. Tapia, M.E. Mountain Agrobiodiversity in Peru. Mt. Res. Dev. 2000, 20, 220-225. [CrossRef]

65. Grau, A.; Brown, A.D. Development Threats to Biodiversity and Opportunities for Conservation in the Mountain Ranges of the Upper Bermejo River Basin, NW Argentina and SW Bolivia. AMBIO J. Hum. Environ. 2000, 29, 445-450. [CrossRef]

66. Joshi, B.K.; Ojha, P.; Gauchan, D.; Ghimire, K.H.; KC, H. Nutritionally unique native crop landraces from mountain Nepal for geographical indication right. In Traditional Crop Biodiversity for Mountain Food and Nutrition Security in Nepal; Gauchan, D., Joshi, B.K., Bhandari, B., Manandhar, H.K., Jarvis, D.I., Eds.; Tools and Research Results of UNEP GEF Local Crop Project, Nepal; NARC, LI-BIRD and the Alliance of Bioversity International and CIAT: Kathmandu, Nepal, 2020.

67. Rocha, F.; Bettencourt, E.; Gaspar, C. Genetic erosion assessment through the re-collecting of crop germplasm. Plant Genet. Resour. Newsl. 2008, 154, 6-13.

68. Hammer, K.; Laghetti, G. Small Agricultural Islands and Plant Genetic Resources. In Le Piccole Isole Rurali Italiane; Istituto di Genetica Vegetale (IGV); Consiglio Nazionale delle Ricerche (CNR): Bari, Italy, 2006.

69. Diederichsen, A.; Hammer, K.; Laghetti, G. Small Agricultural Islands and Plant Genetic Resources. Genet. Resour. Crop Evol. 2007, 54, 683-684. [CrossRef]

70. Scholten, M.; Green, M.; Campbell, G.; Maxted, N.; Ford-Lloyd, B.; Ambrose, M.; Spoor, B. Landrace Inventory of the UK. In European Landraces on-Farm Conservation Management Use; Negri, V., Raggi, L., Maxted, N., Eds.; University of Perugia: Perugia, Italy, 2019; pp. 161-170.

71. Bullitta, S.; Cifarelli, S.; Gadis, T.; Hammer, K. Collecting Crop Genetic Resources in the Mediterranean Agricultural Islands: Corsica (Part I-Northern Corsica); International Plant Genetic Resources Institute: Rome, Italy, 2005.

72. Conversa, G.; Lazzizera, C.; Bonasia, A.; Cifarelli, S.; Losavio, F.; Sonnante, G.; Elia, A. Exploring on-farm agro-biodiversity: A study case of vegetable landraces from Puglia region (Italy). Biodivers. Conserv. 2020, 29, 747-770. [CrossRef]

73. Laghetti, G.; Hammer, K.; Perrino, P. Collecting in northwest Italy. Plant Genet. Res. Newslett. 1993, 91, $23-57$.

74. NORDREGIO. Mountain Areas in Europe: Analysis of Mountain Areas in EU Member states, Acceding and other European Countries. Commissioned Report by the European Commission-DG Regional Policy; Nordregio: Brussels, Belgium, 2004.

75. Keenleyside, C.; Tucker, G.M. Farmland Abandonment in the EU: An Assessment of Trends and Prospects. Report Prepared for WWF; Institute for European Environmental Policy: London, UK, 2010.

76. Terres, J.M.; Nisini, L.; Anguiano, E. Assessing the Risk of Farmland Abandonment in the EU. Final Report EUR 25783EN; Joint Research Centre of the European Commission: Luxembourg; Geel, Belgium, 2013.

77. Cislaghi, A.; Giupponi, L.; Tamburini, A.; Giorgi, A.; Bischetti, G.B. The effects of mountain grazing abandonment on plant community, forage value and soil properties: Observations and field measurements in an alpine area. Catena 2019, 181, 104086. [CrossRef]

78. Giupponi, L.; Leoni, V. VegeT: An easy tool to classify and facilitate the management of seminatural grasslands and dynamically connected vegetation of the Alps. Land 2020, 9, 473. [CrossRef]

79. Peres, S. Saving the gene pool for the future: Seed banks as archives. Stud. Hist. Philos. Sci. Part C Stud. Hist. Philos. Biol. Biomed. Sci. 2016, 55, 96-104. [CrossRef]

80. O'Donnell, K.; Sharrock, S. The contribution of botanic gardens to ex situ conservation through seed banking. Plant Divers. 2017, 39, 373-378. [CrossRef] [PubMed] 